\title{
ANALISIS PENGARUH PASAR SAHAM TERHADAP PERTUMBUHAN EKONOMI DI NEGARA BERKEMBANG (SUATU KAJIAN LITERATUR)
}

\author{
Sulistyowati \\ Institut Islam Mamba'ul'ulum Surakarta \\ suliscan65@gmail.com \\ Marini FitriRahmawati \\ UniversitasSebelasmaret \\ marinifr2@gmail.com
}

\begin{abstract}
ABSTRAK
Sebelum membeli saham diperlukan suatu analisis saham untuk menentukan apakah saham tersebut layak untuk dibeli atau tidak dan untuk mengetahui harga saham tersebut mahal atau tidak.Produk pasar modal selalu berkembang sesuai dengan kebutuhan dan kemampuan infrastruktur pasar. Tujuan dari makalah iniyaituuntukmengetahuianalisispengaruhpasarsahamterhadappertumbuhanekonomi di Negara berkembang.Metode yang digunakanadalahpendekatan eksploratif melalui kajian literatur.Hasilkajian literature menunjukkan(1) ada dua metode yang biasa digunakan oleh para analis untuk menganalisis harga saham, yaitu: analisis fundamental,dananalisa teknikal;(2) pasar modal mempunyai peran dan manfaat, antara lain: (a) Pasar modal merupakan wahana pengalokasian dana secara efisien, (b) Pasar modal memberikan altrenatif investasi, (c) Pasar modal memungkinkan para investor memiliki perusahaan yang sehat dan berprospek baik, (d) Pelaksanaan manajemen perusahaan secara profesional dan transparan, (e) Peningkatan aktivitas ekonomi nasional; (3) Analisis menunjukkan bahwa pengembangan pasar saham secara signifikan memberikan kontribusi terhadap pertumbuhan ekonomi. Hal ini terbukti dalam semua proxy untuk indikator pembangunan keuangan.
\end{abstract}

Kata Kunci: aktivitasinvestasi, pembiayaan modal, UKM.

\begin{abstract}
Before buying shares, a stock analysis is needed to determine whether the stock is worth buying or not and to find out whether the stock price is expensive or not. Capital market products always develop according to the needs and capabilities of market inf rastructure. The purpose of this paper is to find out the analysis of the influence of the stock market on economic growth in developing countries. The method used is an exploratory approach through literature review. The results of the literature review show (1) there are two methods commonly used by analysts to analyze stock prices, namely: fundamental analysis, and technical analysis; (2) capital markets have roles and benefits, including: (a) The capital market is a vehicle for efficient allocation of funds, (b) The capital market provides an alternative investment, (c) The capital market allows investors to have a good and prospective company. (d) Implementation of professional and transparent company management, (e) Increased national economic activities; (3) Analysis shows that the development of the stock market significantly contributes to economic growth. This is evident in all proxies for financial development indicators.
\end{abstract}

Keyword: investment activities, capital financing, UKM. 


\section{PENDAHULUAN}

Sektor ekonomi merupakan sektor sentral dalam suatu negara, terjadinya perubahan dalam perekonomian akan mempengaruhi berbagai sektor dalam kehidupan masyarakat seperti: sosial, politik, budaya dan sebagainya.

Perekonomian juga mempengaruhi pembangunan yang sedang berlangsung, karena pembangunan suatu negara dapat dikatakan berhasil apabila tingkat perekonomian di negara tersebut menunjukkan perkembangan yang positif.

Investasi merupakan salah satu indikator yang dapat mempengaruhi perekonomian di suatu negara. Investasi dikatakan mempengaruhi perekonomian apabila investasi tersebut digunakan untuk melakukan pembiayaan pada sektor riil sehingga apabila sektor riil telah berkembang dengan baik maka output nasional pun akan meningkat. Pembiayaan sektor riil ini dapat dilakukan melalui sektor perbankan dan sektor keuangan lainnya seperti pasar modal.

Berdasarkan Keppres No. 60 tahun 1988, pasar modal merupakan sarana mempertemukan penawar dan peminta dana jangka panjang dalam bentuk efek, baik yang diterbitkan oleh pemerintah (public authorities) maupun perusahaan swasta (private sectors). Pasar modal menyediakan berbagai alternatif investasi bagi para investor selain alternatif lainnya yaitu menabung di bank, membeli emas, asuransi, tanah dan bangunan. Pasar modal bertindak sebagai penghubung antara para investor dengan perusahaan ataupun institusi pemerintah melalui perdagangan instrumen keuangan jangka panjang seperti obligasi, saham.

Perkembangan pasar modal dapat dilihat dari indikator pasar modal lainnya yaitu instrumen kapitalisasi saham. Nilai kapitalisasi saham merupakan jumlah total dari berbagai macam saham dan obligasi yang berada di pasar modal sesuai dengan harga penutupan regularnya. Apabila nilai kapitalisasi saham terus meningkat maka mengindikasikan terjadinya pertumbuhan yang positif dari pasar modal. Perkembangan yang positif dari pasar modal tentu saja akan meningkatkan sumber modal dalam negeri. Apabila sumber modal dalam negeri meningkat maka diharapkan tersedia dana untuk melakukan pembangunan ekonomi sehingga perekonomian dapat berkembang ke arah yang positif.

Analisis menunjukkan bahwa pengembangan pasar saham secara signifikan memberikan kontribusi terhadap pertumbuhan ekonomi. Hal 
ini terbukti dalam semua proxy untuk indikator pembangunan keuangan. Indikator individu pengembangan pasar saham menunjukkan bahwa nilai perdagangan mempengaruhi tingkat pertumbuhan ekonomi tetapi kapitalisasi pasar bukan cara yang benar untuk mempercepat pertumbuhan ekonomi di negara berkembang (Nais \& Puja, 2015: 87). Masoud \& Glenn (2012: 56) menyatakan bahwa:

Pengembangan pasar saham memiliki pengaruh yang signifikan terhadap pertumbuhan ekonomi, dan efek ini tetap kuat bahkan setelah pengaruh sektor perbankan dan variabel kontrol lainnya menggunakan model pertumbuhan; (2) Temuan penelitian tersebut mendukung pandangan bahwa hubungan jangka panjang keseimbangan antara evolusi pasar saham dan evolusi ekonomi bersifat stabil.

Pasar saham telah memainkan peran penting di pasar negara berkembang. Hubungan antara pembangunan pasar saham dan pertumbuhan ekonomi telah diakui sebagai hubungan yang kuat, bahkan setelah mengontrol variabel ekonomi yang terkait dengan tingkat pertumbuhan. Ukuran pasar saham yang diukur dengan rasio kapitalisasi pasar secara statistik berkorelasi positif dan signifikan dengan tingkat pertumbuhan GDP per kapita. Dua indikator likuiditas, nilaidiperdagangkan dan omset rasio, secara statistik juga berkorelasi positif dan signifikan dengan tingkat pertumbuhan GDP per kapita. Selain itu muncul dari pekerjaan ini yang perbankan indikator pembangunan sektor masuk secara signifikan dalam regresi pertumbuhan. Selain menekankan bahwa pengembangan sektor keuangan di pasar berkembang adalah signifikan dalam prosesnya pertumbuhan ekonomi, penelitian ini menunjukkan bahwa bank-berbasis melakukan fungsi yang berbeda dari yang dilakukan oleh pasar berbasis saham.

Penulis dalam makalah ini menemukan bahwa semua variabel kecuali inflasi, memiliki dampak signifikan pada tingkat pertumbuhan ekonomi. Koefisien tidak signifikan untuk inflasi konsisten dengan banyak penelitian sebelumnya (Beck et al., 2000; Christopolous dan Tsionas; 2004). Rasio investasi dan keterbukaan perdagangan berpengaruh positif dan sangat signifikan dalam mempengaruhi tingkat pertumbuhan ekonomi, selain itu nilai tukar menunjukkan hubungan negatif dan signifikan terhadap pertumbuhan ekonomi, hal ini menunjukkan bahwa pengelolaan 
nilai tukar yang buruk membuat tingkat pertumbuhan ekonomi menjadi menurun.

Pasar modal di negara berkembang mempunyai konsekuensi nilai kapitalisasi pasarnya yang kecil. Kapitalisasi pasar biasanya dilihat dari rasio perbandingan dengan nilai Produk Domestik Bruto (PDB) suatu negara. Konsekuensi lainnya adalah terdapatnya volume transaksi perdagangan yang tipis, lebih disebabkan oleh ketidaksinkronan perdagangan di pasar. Perdagangan yang tidak sinkron disebabkan oleh banyaknya sekuritas yang tercatat, tetapi tidak seluruhnya diperdagangkan atau tidak terjadi transaksi.Berdasarkan latar belakang diatas, maka penulis tertarik untuk menulis makalah dengan judul

"Analisis Pasar Saham terhadap Pertumbuhan Ekonomi di Negara Berkembang".

\section{METODE PENELITIAN}

Makalah ini ditulis dengan menggunakan pendekatan eksploratif melalui kajian literatur. Pendekatan eksploratif adalah jenis pendekatan yang bertujuan ingin menggali secara luas tentang sebab-sebab atau hal-hal yang mempengaruhi terjadi suatu peristiwa (Arikunto: 2006,7). Melalui pendekatan eksploratif ini bermaksud mencari sebanyak mungkin sumber-sumber informasi yang berhubungan dengan rumusan masalah yang hendak dikaji. Teknik pengumpulan data yang digunakan berupa kajian literatur. Teknik ini mengumpulkan sumber-sumber informasi ilmiah yang diperoleh dari beberapa karya ilmiah, baik yang diperoleh dari jurnal, koran, majalah dan sumber-sumber lain yang mendukung tujuan penulisan.

\section{PEMBAHASAN}

Analisis Saham

Sebelum membeli saham diperlukan suatu analisis saham untuk menentukan apakah saham tersebut layak untuk dibeli atau tidak dan untuk mengetahui harga saham tersebut mahal atau tidak. Menurut Syamsudin (2007: 67), ada dua metode yang biasa digunakan oleh para analis untuk menganalisis harga saham, yaitu:

1) Analisis Fundamental/ Fundamental Analysis

Analisis Fundamental adalah analisa yang mempelajari hubungan antar harga saham dengan kondisi perusahaan, dengan melihat pada indikator ekonomi terutama yang berkaitan dengan penampilan perusahaan seperti volume penjualan, kekayaan, keuntungan, dan sebagainya. Analisa fundamental dilakukan 
dengan tujuan pada aspek-aspek yang fundamental dari suatu perusahaan yang terjun ke pasar modal. Secara garis besar, pendekataan fundamental analysis menilai investasi dalam bentuk deviden dan prospek perusahaan.

$$
\text { Pada dasarnya }
$$

pendekatan ini memberikan penekanan pada nilai atau harga suatu saham yang didasarkan pada nilai atau harga suatu saham yang didasarkan pada tingkat pendapatan (return) yang akan diperoleh dari saham tersebut. Cara yang ditempuh adalah dengan melakukan perhitungan atas laporan keuangan perusahaan sehingga akan didapat rasio-rasio keuangan yang merupakan informasi dari emiten.

2) Analisa Teknikal/ Technical Analysis

Analisa ini merupakaan kebalikan dari analisa fundamental karena lebih menekankan pada faktor-faktor eksternal perusahaan emiten yang mempengaruhi naik turunnya harga saham serta naik turunnya permintaan dan penawaran saham. Cara yang digunakan untuk menganalisa saham yaitu dengan cara megamati harga saham selama beberapa periode, kemudian dibuat suatu grafik/tabel. Pendekatan seperti ini berpendapat bahwa harga saham dipengaruhi oleh suatu alur mode tertentu, tanpa mengesampingkan faktor-faktor eksternal perusahaan, seperti kebijakan ekonomi dan lain sebagainnya.

\section{Peran dan Manfaat Pasar Modal}

Menurut Tjiptono (2006: 10), Pasar Modal mempunyai peran dan manfaat, antara lain: (1) Pasar modal merupakan wahana pengalokasian dana secara efisien. Dimana investor dapat melakukan investasi pada beberapa perusahaan melalui pembelian efek-efek yang diperdagangkan di pasar modal. Sebaliknya perusahaan dapat memperoleh dana yang dibutuhkan dengan menawarkan instrument keuangan jangka panjang melalui pasar modal tersebut; (2) Pasar modal memberikan altrenatif investasi. Di mana pasar modal memudahkan alternatif berinvestasi yang memberikan keuntungan dengan sejumlah resiko tertentu; (3) Pasar modal memungkinkan para investor memiliki perusahaan yang sehat dan berprospek baik. Dimana perusahaan yang sehat dan memiliki prospek yang baik tidak hanya 
dimiliki oleh sejumlah orang tertentu saja. Penyebaran kepemilikan secara luas dapat mendorong perkembangan perusahaan menjadi lebih transparan; (4) Pelaksanaan manajemen perusahaan secara profesional dan transparan. Keikutsertaan masyarakat dalam kepemilikan perusahaan mendorong perusahaan untuk menerapkan manajemen secara lebih profesional, efisien dan berorientasi pada keuntungan sehingga tercipta kondisi "good corporate governance".

BAPEPAM menganjurkan setiap perusahaan publik memiliki suatu komite audit; (5) Peningkatan aktivitas ekonomi nasional. Dengan adanya pasar modal perusahaan akan lebih mudah memperoleh dana sehingga akan mendorong perekonomian nasional menjadi lebih maju dan menciptakan kesempatan kerja yang luas serta meningkatkan pendapatan pajak bagi pemerintah.

\section{Konsep Pertumbuhan Ekonomi}

Secara ekonomi, ada beberapa cara untuk memperhitungkan pertumbuhan ekonomi, baik dilihat dari sisi permintaan maupun jika dilihat dari sisi penawaran. Apabila dari sisi permintaan (demand) yaitu dengan memperhitungkan komponenkomponen makro ekonomi berupa konsumsi, investasi, ekspor dan impor sedangkan dari sisi penawaran (supply) dengan memperhitungkan nilai tambah setiap sektor dalam produksi nasional.

Laju pertumbuhan ekonomi akan diukur melalui indikator perkembangan PDB atau PNB dari tahun ke tahun. Adapun cara menghitung laju pertumbuhan dilakukan dengan tiga metode yaitu: (1) cara tahunan; (2) cara rata-rata setiap tahun; dan (3) cara compounding factor. Pengukuran pertumbuhan ekonomi secara konvensional biasanya dengan menghitung peningkatan presentase dari Produk Domestik Bruto (PDB).

PDB mengukur pengeluaran total dari suatu perekonomian terhadap berbagai barang dan jasa yang baru diproduksi pada suatu saat atau tahun serta pendapatan total yang diterima dari adanya seluruh produksi barang dan jasa tersebut atau secara lebih rinci, PDB adalah nilai pasar dari semua barang dan jasa yang diproduksi di suatu negara dalam kurun waktu tertentu (Gregory, 2012:126). Pertumbuhan biasanya dihitung dalam nilai riil dengan tujuan untuk menghilangkan adanya inflasi dalam harga dan jasa yang diproduksi sehingga PDB riil mencerminkan perubahan kuantitas produksi. 


\section{Pasar Modal dan Pertumbuhan Ekonomi}

Pasar modal adalah instrumen keuangan yang memperjual belikan surat-surat berharga berupa obligasi saham untuk jangka panjang yang diterbitkan oleh pemerintah maupun perusahaan swasta, dan kegiatannya dilaksanakan di bursa dimana tempat bertemunya para pialang yang mewakili investor. Perkembangan pasar modal berpengaruh terhadap pertumbuhan ekonomi nasional, pentingnya peran pasar modal dalam mendorong pertumbuhan ekonomi nasional terlihat dari perkembangan pasar modal akan berpengaruh pada indikator-indikator makro ekonomi seperti nilai tukar riil, tingkat inflasi, dan juga pertumbuhan ekonomi yang diukur berdasarkan produk domestik bruto riil. Pada akhirnya perubahan pertumbuhan nilai tukar, pertumbuahan investasi riil, pertumbuhan tingkat inflasi, dan neraca pembayaran akan berpengaruh pada pertumbuhan ekonomi dan menghasilkan trickle down-effect yang bermuara pada perbaikan tingkat kesejahteraan masyarakat secara keseluruhan. Di Indonesia perkembangan pasar modal memberikan sumbangsih terhadap pertumbuhan ekonomi terutama dari pembayaran pajak.
Perkembangan pasar modal yang tinggi akan membawa perekonomian pasa surplus neraca pembayaran karena tingkat aliran dana yang berasal dari luar negeri lebih cepat dibandingkan tingkat aliran barang, sehingga terjadi balance of payment surplus. Pada akhirnya perubahan pertumbuhan nilai tukar, pertumbuahan investasi riil, pertumbuhan tingkat inflasi, dan neraca pembayaran akan berpengaruh pada pertumbuhan ekonomi dan menghasilkan trickle down effect yang bermuara pada perbaikan tingkat kesejahteraan masyarakat secara keseluruhan.

\section{KESIMPULAN}

Berdasarkan kajian literatur diatas, maka dapat disimpulkan bahwa: (1) ada dua metode yang biasa digunakan oleh para analis untuk menganalisis harga saham, yaitu: analisis fundamental/fundamental analysis, analisa teknikal/ technical analysis; (2) pasar modal mempunyai peran dan manfaat, antara lain: (a) Pasar modal merupakan wahana pengalokasian dana secara efisien, (b) Pasar modal memberikan altrenatif investasi, (c) Pasar modal memungkinkan para investor memiliki perusahaan yang sehat dan berprospek baik, (d) Pelaksanaan manajemen perusahaan secara 
profesional dan transparan, (e) Peningkatan aktivitas ekonomi nasional; (3) Analisis menunjukkan bahwa pengembangan pasar saham secara signifikan memberikan kontribusi terhadap pertumbuhan ekonomi. Hal ini terbukti dalam semua proxy untuk indikator pembangunan keuangan.

Berdasarkankesimpulandiat as, maka saran darihasil kajian ini adalah:(1) cara investor sebaiknya memperhatikan poin-poin penting sebelum mengambil keputusan untuk berinvestasi; (2) Investor sebaiknya lebih meningkatkan investasi, untuk membantu perekonomian suau negara.

\section{REFERENSI}

Arikunto, S. (2006). Prosedur Penelitian Suatu Pendekatan Praktik. Jakarta: PT Rineka Cipta.

Gregory,

$$
\text { M., }
$$
$\mathrm{N}$. (2012).PengantarEkonomiMak ro. Jakarta: Erlangga.

Keputusan Presiden Republik Indonesia No.60 Tahun 1988 tentang Pasar Modal. http://www.legislasi.mahkamah agung.go.id/.../KEPPRES/KEP PRES_1988_60_PASAR\%20 MODAL.pdf. Diakses tanggal 23 April 2017.

Masoud, N., \& Glenn, H. (2012) The impact of financial development on economic growth: Empirical analysis of emerging market countries", Studies in
Economics and Finance. Vol. 29 Issue: 3, pp.148173.

Naik, P., K., \& Puja, P. (2015). On the linkage between stock market development and economic growth in emerging market economies: Dynamic panel evidence. Review of Accounting and Finance. Vol. 14, Issue: 4, pp. 363-381.

Syamsudin, L. (2007). Manajemen keuangan perusahaan. Jakarta: Raja Grafindo Persada.

Tjiptono, F. (2006).ManajemenJasaEdisiPe rtama. Yogyakarta: Andi. 